\title{
Prisoners of the Capitalist Machine: Captivity and the Corporate Engineer
}

Eddie Conlon

Technological University Dublin, edward.conlon@tudublin.ie

Follow this and additional works at: https://arrow.tudublin.ie/engineducbks

Part of the Engineering Education Commons, and the Other Engineering Commons

\section{Recommended Citation}

Conlon E. (2019) Prisoners of the Capitalist Machine: Captivity and the Corporate Engineer. In:

Christensen S., Delahousse B., Didier C., Meganck M., Murphy M. (eds) The Engineering-Business Nexus. Philosophy of Engineering and Technology, vol 32. Springer, Cham. DOI: 10.1007/978-3-319-99636-3_3

This Book Chapter is brought to you for free and open access by the Engineering: Education and Innovation at ARROW@TU Dublin. It has been accepted for inclusion in Books/Book chapters by an authorized administrator of ARROW@TU Dublin. For more information, please contact arrow.admin@tudublin.ie, aisling.coyne@tudublin.ie,gerard.connolly@tudublin.ie.

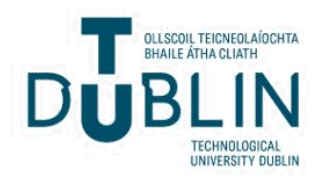


Pre Publication Copy.Refer to book for page numbers when quoting

This is chapter 3 of Steen Hyldgaard Christensen, Bernard Delahousse • Christelle Didi-

er,Martin Meganck • Mike Murphy (eds)

The Engineering-Business Nexus:Symbiosis, Tension and Co-Evolution. Springer, 2019. It

appears on pages $39-59$

\title{
Chapter 3 \\ Prisoners of the Capitalist Machine Captivity and the Corporate Engineer
}

\author{
Eddie Conlon
}

\begin{abstract}
This chapter will focus on how engineering practice is conditioned by an economic system which promotes production for profit and economic growth as an end in itself. As such it will focus on the notion of the captivity of engineering which emanates from features of the economic system. By drawing on Critical Realism and a Marxist literature, and by focusing on the issues of safety and sustainability (in particular the issue of climate change), it will examine the extent to which disasters and workplace accidents result from the economic imperative for profitable production and how efforts by engineers to address climate change are undermined by an on-going commitment to growth. It will conclude by arguing that the structural constraints on engineering practice require new approaches to teaching engineers about ethics and social responsibility. It will argue that Critical Realism offers a framework for the teaching of engineering ethics which would pay proper attention to the structural context of engineers work without eliminating the possibility of engineers working for radical change.
\end{abstract}

Keywords: capitalism; captivity; Marxism; Critical Realism, engineering ethics

\section{Introduction}

Capitalism as a socio-economic form of life continues to have overwhelming causal importance in shaping the geographical distribution of economic activity, the life chances of whole categories of people, the availability of policy-options for dealing with pressing economic, social and ecological problems and so on. In the wake of the neo-liberal ascendency and capitalist globalization this is even more inescapably so (Benton and Craib 2011, p.209).

It seems we are all prisoners of the capitalist machine ${ }^{1}$. Like other categories of people capitalism matters to engineers. And engineers matter to capitalism: economic growth is dependent on a process of continual technological renewal and change. Big corporations, some with value greater than some countries GNP, with managers, not entrepreneurs, at the centre of them, are the organizational form that has come to represent growth. Therefore engineers and managers are central features of contemporary capitalist society.

Engineers and managers are also central to many case studies that engineering students study as part of engineering ethics programs. This chapter aims to situate these conflicts between engineers and managers within the broader forces shaping the employment relationship and the operation of capitalist economies. Critical Realism offers a useful philosophical framework for doing this, given its depth ontology which forces us to focus on underlying structures which shape human practices. Marxism offers one way of understanding these underlying structures and remains

${ }^{1}$ My title is inspired by Mike Davis's study of the American working class, Prisoners of the American Dream, London and New York: Verso, 1986. 
Pre Publication Copy.Refer to book for page numbers when quoting

This is chapter 3 of Steen Hyldgaard Christensen, Bernard Delahousse • Christelle Didier,Martin Meganck • Mike Murphy (eds)

The Engineering-Business Nexus:Symbiosis, Tension and Co-Evolution. Springer, 2019. It appears on pages $39-59$

the most influential account of the employment relationship within sociological theory and one that has a profound effect on all disciplines concerned with work (Browne 1988, Thompson and Mc Hugh 2002). It will be argued that the aspiration of engineers to hold paramount the welfare of the public is conditioned by an economic system which promotes production for profit and operates through hierarchical organisational forms which shape the relations between engineers and managers. This is not to say that the actions of engineers are crudely determined by the imperatives of profitable production but that, as Althusser might say (see Craib 1992), they are "determined in the last instance" by the requirement of the capitalist mode of production which "shapes behaviour not by fixing exactly what people do but by establishing boundaries and limits" (Korczynski et. al 2006, p.14). I want to emphasise the embeddedness of engineering practice arising from the totality constituted by capitalist society and the structural constraints on the engineers role and therefore defend the conceptualisation of engineering as a captive profession (Noble 1977, Goldman 1991, Holt 2001, Conlon 2013).

I proceed by discussing some features of Critical Realism and the structure of capitalist economies derived from Marxism. The position of engineers within this structure is then explored. It is argued that although relations between engineers and managers have specific characteristics in different capitalist economies they are conditioned by the dynamics of class relations, which create contradictory demands on engineers, but also place limits on engineering practice especially when it collides with corporate priorities. The limits on engineering practice are explored further by an examination of the issues of safety and engineers' roles in addressing climate change, in the context of an increasingly neo-liberal business environment. The conclusion will focus on how Critical Realism can contribute to developing an approach to engineering ethics which will enable future engineers to understand the full range of issues they will be required to address in order hold paramount the health, safety and welfare of the public. To escape captivity engineers will need to confront constraints arising from the business environment.

\section{Critical Realism}

In the social sciences Critical Realism (CR) has emerged as an alternative paradigm to positivism and interpretivism. It combines a realist ontology with an interpretive epistemology: the real world exists independently of our knowledge of it and our knowledge of the world is always fallible as it is shaped by the "social position of knowers" (Carter and New 2004, p. 2). CR argues for the primacy of ontology. In seeking to explain phenomena it offers a distinctive approach. Firstly, a depth ontology: a notion of a stratified reality which includes a distinction between the domain of the real (generative mechanisms), the actual (events) and the empirical (experiences). Structures of objects, at the level of the real, generate mechanisms that facilitate events. Realist explanations connect experience in the empirical domain with structures and processes in the real domain. We are encouraged to look "at deeper structural things that might be the cause of events" (Kotta 2011). This is potentially emancipatory in that it forces us to consider "that certain states of affairs 
Pre Publication Copy.Refer to book for page numbers when quoting

This is chapter 3 of Steen Hyldgaard Christensen, Bernard Delahousse • Christelle Didier,Martin Meganck • Mike Murphy (eds)

The Engineering-Business Nexus:Symbiosis, Tension and Co-Evolution. Springer, 2019. It appears on pages $39-59$

cannot be ameliorated within existing structures". (Collier 1994, p.10). They must be changed.

While arguing that the social can be studied scientifically critical realists also argue there are differences between the natural and social sciences. Firstly, taking the conduct of experiments as a starting point, CR argues that the kind of closure offered by laboratory experiments is not achievable in the real world. Therefore causal mechanisms must be studied as part of open systems where their effects may be blocked by the operation of other mechanisms (Danermark et al 2002). Thus their impact is conditioned by the context in which they operate.

Secondly, social structures are maintained through the activity of people. CR offers a particular social ontology focused on the relationship between structure and agency and is committed to an explanatory model "in which the interplay between pre-existent structures, possessing causal powers...and people possessing causal powers... of their own results in contingent yet explicable outcomes" (Carter and New 2004, p.6). This implies that any investigation can only take place "at the intersection...of agental and structural objects" (Scott 2007, p.15). Margaret Archer (1995) argues that social theory has come up with unsatisfactory ways to understand this relationship and provides a framework for understanding different approaches by focusing on what she calls varieties of conflationism. On the one hand there is downward conflation which emphasises the determining effect of social structures and allows very little role for intentional human activity in explaining social forms. On the other hand there is upward conflation which places undue emphasis on the creative and intentional dimension of human activity. She identifies a third kind of central conflationism, which see agency and structure as "mutually constitutive" and fundamentally inseparable.

$\mathrm{CR}$ is committed to analytical dualism in that structure and agency are seen as objects of a radically different type possessing different properties and powers (Carter and New 2004). For the latter these include self-consciousness, reflexivity and intentionality. The key properties of social structures are anteriority (they are pre-existing features of the world we are born into) and that they are relatively enduring. Among the powers possessed by social structures are those of enablement and constraint. Thus the tranformative potential inherent in human agency can only "begin to bite when structural contexts ...are generally supportive of those potentialities being actualised in some durable form." (Reed 2005, p.302). In this account social structures are seen to be causally efficacious: "People choose what they do, but they make their choices from a structurally and culturally determined range of options - which they do not choose" (Carter and New 2004, p.3).

\section{The Social Structure}

This is very much in the spirit of the oft quoted statement from Karl Marx that "Men (sic) make their own history, but they do not make it as they please; they do not make it under circumstances of their own choosing but, under circumstances existing already, given and transmitted from the past" (Marx 1954) and highlights the close affinity between CR and Marxism (Benton and Craib 2011). Marxism offers 
Pre Publication Copy.Refer to book for page numbers when quoting

This is chapter 3 of Steen Hyldgaard Christensen, Bernard Delahousse • Christelle Didier,Martin Meganck • Mike Murphy (eds)

The Engineering-Business Nexus:Symbiosis, Tension and Co-Evolution. Springer, 2019. It appears on pages $39-59$

one way of understanding deeper structures and the underlying mechanisms which shape the operation of capitalist societies and, consequently, business practices.

Drawing on Marx, Douglas Porpora provides a definition of the social structure as "a causal mechanism constituted by the relationships among social positions that account for social phenomena in terms of tendencies, strains and forces inherent in the nexus of these relationships" (1998, p.340). In the Marxist tradition, he says, the systems of social relationships referred to are modes of production, social positions are class positions and human relationships are class and intraclass relations such as domination, competition and exploitation. In realist terms Marxist analysis seeks to explain the tendential properties of capitalism in terms of its internal structure. Thus the internal structure of capitalism: involving minority ownership of the means of production; production for profit by competing firms operating in a market economy and a class of workers who live by selling their labour power; has certain deleterious tendencies. These include the growth in monopolies and a concentration of wealth, crises of overproduction, the degradation of work and conflicts of interests based on a "structured antagonism...in which the workers' ability to work is deployed in the creation of a surplus that goes to another group" (Edwards 1986, p.5).

What is useful in this approach is that it takes us beyond the common-sense understanding, endorsed by much mainstream theory, of the wage contract as a fair exchange between freely contracting parties to a focus on the underlying "coercive relations of power and domination which characterises the process of production" (Benton and Craib 2011, p.137). Domination is seen as intrinsic rather than being pathological or temporary as most forms of organisational analysis might suggest (Thompson and Mc Hugh 2002). We are also encouraged to challenge the view that corporations are rational enterprises pursuing goals to satisfy the interests of all. The focus shifts to how they pursue the interests of elites at the expense of others.

There are a number of elements of a Marxist analysis of the employment relationship that can be noted (Browne 1998, Hyman 2006). Firstly workers are capable of creating greater value than the cost of maintaining them and the means of production. The employer wants to produce commodities that embody surplus value. Worker activity contributes to the production of use value and exchange value which generates surplus value which goes to their employer. Thus the production process is simultaneously a production and valorisation process. Secondly, when they sell their labor workers agree not to expend a particular amount of effort but rather to make their capacity to work available to their employer. Because of this indeterminacy of labor potential control exercised by the employer, or their representatives, is necessary to ensure that the work the workers has been hired to do is actually done. Thus the labor process is organized hierarchically and employers build relations of control into the structure of the labor process. Class divisions are thus institutionalized in the workplace particularly between managers (and engineers) involved in the design and control of work and workers involved in productive activity (Meiksins and Smith 1996, Morgan 1997).

In understanding the issue of control in the workplace it is important to acknowledge the essentially contradictory requirements facing management:

The function of labour control involves both the direction, surveillance and discipline of subordinates whose enthusiastic commitment to corporate objectives cannot be taken for granted; and 
Pre Publication Copy.Refer to book for page numbers when quoting

This is chapter 3 of Steen Hyldgaard Christensen, Bernard Delahousse • Christelle Didier,Martin Meganck • Mike Murphy (eds)

The Engineering-Business Nexus:Symbiosis, Tension and Co-Evolution. Springer, 2019. It appears on pages 39-59

the mobilisation of the discretion, initiative and diligence which coercive supervision, far from guaranteeing is likely to destroy (Hyman 1987, p.41).

Therefore there is not just one strategy for control, such as Scientific Management and its attendant deskilling as argued by Braverman (1974) and others, such as the engineer Mike Cooley (see Smith 1987), who have drawn on Braverman to argue that there was an inherent tendency in capitalism to use technology to deskill technical workers, such as engineers. There are a variety of control strategies available to managers which are shaped by workers skills, market conditions, technology and also worker resistance. This suggests there are constraints on what managers can do. A narrow focus on deskilling and profit maximisation may undermine the social relations necessary for ensuring successful valorisation (Mac Kenzie 1996). It is not always necessary or possible to eliminate worker discretion and exercise direct and detailed control over work tasks. One typology (Friedman 1977) distinguishes between direct control and responsible autonomy which aims to use worker's creativity by permitting them a large amount of discretion. The latter is often used with skilled and knowledge workers.

A further distinction has been drawn between detailed and general control (Edwards 1986). Even where employers do not seek direct control a set of arrangements are still required which ensures that workers are accommodated to the overall aim of the enterprise. Thus control can be exercised outside the actual performance of work tasks through the operation of internal labor markets and promotion structures.

A third feature of the employment relationship is that it is based on an asymmetry of power. The individual owner of labour power is less likely to be able to afford to be unemployed than the individual capitalist is likely to be able to refrain from employing her. This is not to suggest that there is not conflict over the terms of employment or the organisation of the labor process. The capacity of workers to resist management is based on what Wright (1979) calls their structural and organisational capacities usually expressed in trade union membership. While the state in capitalist societies depends on the flourishing of the accumulation process and seeks to induce workers (sometimes using force) to refrain from using their organisational power, it can also play a role, depending on its character, in underwriting workers rights. Indeed, Michael Burawoy (1985) has argued that the character of what he calls "factory regimes" is shaped by state intervention. He traces a shift from the despotic regimes of early capitalism to more hegemonic regimes facilitated by state intervention, through social insurance legislation and regulation of the employer/worker relationship, reducing worker' dependence on their sale of labour power. But, he claims, that with the globalisation of capital a new era of "hegemonic despotism" has emerged replacing the fear of being fired with the fear of capital flight. Combined with the emergence of neo-liberalism this has led to pressure for deregulation (Harvey 2007).

Focusing wider than the employment relationship we should note the central contradiction in capitalist societies of the gap between what technology could provide for society and what it actually does provide (Cooley 1978). In Marxist terms this refers to the contradiction between the forces and relations of production. The productive capacity of society is fettered by minority ownership and its use to enrich this minority. Thus production is not for need but to ensure capital accumulation. 
Pre Publication Copy.Refer to book for page numbers when quoting

This is chapter 3 of Steen Hyldgaard Christensen, Bernard Delahousse • Christelle Didier,Martin Meganck • Mike Murphy (eds)

The Engineering-Business Nexus:Symbiosis, Tension and Co-Evolution. Springer, 2019. It

appears on pages 39-59

For Marx the logic of accumulation gives capital "no rest, and continually whispers in its ear: Go on! Go on" (Quoted in Magdoff and Foster 2011, p.38). The motivating force of capitalism is the never-ending quest for profits and accumulation. Because of competition companies are impelled to continually increase sales and gain a bigger market share. What this means is that capitalism is always about growth. The result is production for the sake of production and the expansion of consumption to such an extent that there has been an explosion of "consumption linked to increasing wasteful lifestyles, often financed by growing household debt". (Magdoff and Foster 2011, p.48, see also Woodhouse 2001). Despite this and the increasing global scale of capitalism the system continues to be subject to periodic crises of overproduction as it has an in-built insufficiency of demand because workers are paid less than the value of the goods they produce.

What are the implications of this approach to understanding business activity for engineers and their relations with business and management? To examine this three issues are discussed below: the place of engineers in the class structure; engineering practice in relation to safety and the role of engineers in relation to climate change.

\section{Engineers in the Social Structure}

As part of its depth ontology CR argues that mechanisms operating at different levels can interact to shape variable social practices across different capitalist societies. An example is Chris Smith and Peter Meiksins (1995) approach, which argues for the need to investigate distinct generative processes (which they call system, society and dominance effects) to explain the strategies of firms. This helps us to understand why the structure and role of the engineering profession and the association between engineers and managers is divergent across similar societies. The key source of this diversity can be located in the timing and route into industrial capitalism (Lee and Smith 1992).

Whilst acknowledging this diversity, Meiksins and Smith (1996) use what they call a "structural contingency" version of Marxist theory to argue for the importance of the underlying dynamics of capitalism, as discussed above, in shaping national patterns:

Societies may differ but this variation must be contextualized within the underlying mode of production which establishes a set of dynamic structuring relationships which establish common problems and a common set of limits within which any capitalist society must operate (Meiksins and Smith 1996, p. 234).

By engaging with Marxist class theory they point to some commonalties across capitalist societies: the increasing complexity, technical sophistication and scale of production and the increase in the number of educated technical workers, including engineers, who either design industrial processes and products and/or oversee or coordinate the functioning of workers or equipment used in production. Drawing on the work of Carchedi (1977) they argue that the position of engineers within enterprises is characterised by a degree of ambiguity and contradiction resulting from the structural realities of capitalism. While many are clearly workers in that they con- 
Pre Publication Copy.Refer to book for page numbers when quoting

This is chapter 3 of Steen Hyldgaard Christensen, Bernard Delahousse • Christelle Didier,Martin Meganck • Mike Murphy (eds)

The Engineering-Business Nexus:Symbiosis, Tension and Co-Evolution. Springer, 2019. It appears on pages 39-59

tribute their mental labour to the production process, others also contribute to the function of the 'collective worker' by coordinating increasingly complex labour processes. But they may also contribute to the 'function of capital' by performing a 'surveillance' function which involves controlling the workforce and harnessing it to the need of the valorisation process. As the capitalist enterprise grows in size and complexity we see the 'collective function of capital' being performed by managers and engineers whose work "involves varying mixes of both coordination (necessary organisation) and surveillance (managing for capital)" (Meiksins and Smith 1996, p.15). Thus the relationships between engineers and managers, and other workers, remains somewhat open:

engineers...may choose to define themselves as labor, manual workers may express solidarity with educated workers or may reject them; employers may, in various ways, shape organizational hierarchies so as to separate... or bring closer together these different elements of the collective laborer (Meiksins and Smith 1996, p.17).

The significance of this is that the position of engineers can be understood in the context of the dynamics of the labor-capital relationship. While the line between engineers and managers may not be as clear as some suggest, it does mean that some engineers are unambiguously members of management and therefore expected to make decisions which reflect their place in the managerial hierarchy (Goldman 1991). As managers they "must represent the interpretation of value judgments in relation to the interests of those on whose behalf they manage" (Holt 2001, p. 498). Their positional power as managers is held and exercised only so long as they serve the interests of those they represent. Indeed they are unlikely to achieve management status until they prove their "dependability and responsibility" and show "they can be trusted by their employers" (Beder 1998, p.21, see also Zussman 1985 and Whalley 1986). Thus it seems unrealistic, and perhaps somewhat moralistic, to expect those who have donned management hats to simply take them off.

Secondly, given the hierarchical organization of the labor process, engineers face pressures pushing them towards management and away from other workers. The use of different control strategies with different categories of workers, and provision for the exercise of responsible autonomy by engineers, may reinforce this tendency (Smith 1987). Even when engineers are performing coordination functions, others may experience this as surveillance and compulsion. So while they are part of the collective labor process, "its hierarchical nature places engineers in the ambiguous position of being part of wage labor, but linked, in various ways, to capital" (pp.1617). Further, given the trajectory of many engineering careers, there is pressure on engineers to conform to both bureaucratic authority and business values making them relatively indistinguishable from management (Whalley 1986). Ethnographic data collected by Kevin Anderson and others (2010) highlights how engineers work is "most significantly" constrained by "organisational business practices relating to time and budgets" (p.169). There is a sense that the "romantic visions" that the engineers had, while at college, were knocked out of them by the "business realities of engineering" (pp.166-7). There are strong pressures on engineers to conform to corporate agendas. These are reinforced by engineering education which, in the 
Pre Publication Copy.Refer to book for page numbers when quoting

This is chapter 3 of Steen Hyldgaard Christensen, Bernard Delahousse • Christelle Didier,Martin Meganck • Mike Murphy (eds)

The Engineering-Business Nexus:Symbiosis, Tension and Co-Evolution. Springer, 2019. It appears on pages $39-59$

main, endorses a market orientated approach to education (Jamison 2013, Conlon 2008, 2013).

Thirdly, whether engineers, in contradictory locations, link with other workers to promote alternatives to the dominant business agenda may be determined by social and political factors (Smith 1987). While Hodson (2001) identifies a "general nonresistance to administrative logics" (p.159) engineers may not always favour management especially when their integration into management hierarchies is weak. So, experiments in work humanisation in Sweden are partially explained by the strong position of trade unions with a wide membership base (including many engineers) and comprehensive legal rights at the workplace. Meiksins and Smith (1996) argue that work humanisation was facilitated because Swedish engineers were closely aligned with manual workers and were engaged in a dialogue with social scientists exposing them to the benefits of work humanization. Similarly, in Britain, the development of the Lucas Aerospace Plan for alternative socially useful production, to replace production for the defence sector, took place in a trade union context which integrated technical and shopfloor workers. Attempts to generalise the experience at Lucas were only successful when technical workers existed as an "organic resource integrated into the trade union structure at plant level" (Smith 1987, p.44). ${ }^{2}$ These experiments though were blocked or undermined because they either challenged managerial prerogative in the Lucas case or by the internationalisation of Swedish capital to escape the constraints' of the local environment (Bowen 2014, Meiksins and Smith 1996). This points to the vulnerability of labor-centered projects in the context of a system that prioritizes some interests at the expense of others and emphasizes how engineering practice is constrained by these interests.

\section{Safety Dilemmas}

The vulnerability of labour is also exposed by even a cursory consideration of issues related to workplace health and safety. In his magnus opus on organisational theory Gareth Morgan says that

$$
\begin{aligned}
& \text { each year hundreds of thousands of workers throughout the world die of work-related accidents } \\
& \text { and illnesses. Despite the major advances in occupational health and safety legislation, the issue } \\
& \text { of costs versus safety looms large on the unofficial agenda in many corporate decisions...In } \\
& \text { many situations 'the bottom line' tends to come first and safety second (1997, pp.302, 316, 320). }
\end{aligned}
$$

The use of a "domination metaphor" to understand organisations forces us to consider that accidents, and other adverse effects of organisations, "may all result from the way systemic forces dictate that business be done" (p. 343).

What he is doing is calling for a widening of our focus, beyond human error and individual responsibility, to understand the underlying causes of accidents. Such a

\footnotetext{
${ }^{2}$ In an interesting contribution to the engineering ethics literature Bowen (2014) also highlights the importance of the trade union context in supporting the development of the Plan.
} 
Pre Publication Copy.Refer to book for page numbers when quoting

This is chapter 3 of Steen Hyldgaard Christensen, Bernard Delahousse • Christelle Didier,Martin Meganck • Mike Murphy (eds)

The Engineering-Business Nexus:Symbiosis, Tension and Co-Evolution. Springer, 2019. It

appears on pages $39-59$

focus seems to be missing from discussions of safety in engineering ethics (see Conlon 2015 and Conlon and Zandvoort 2010). The dominant approach uses case studies to focus on the resolution of ethical dilemmas by individual engineers. These often involve clashes between engineers and managers and focus on the capacity of engineers to resist managerial pressures and/or engage in whistleblowing. It is assumed that not only can ethical problems be solved at the level of the individual but that engineers can act on their solutions. As a result, those using this approach tend to focus on individual failings as the key impediments to responsible action. There seems to be two problems with this approach.

Firstly, it is devoid of context. ${ }^{3}$ As Langdon Winner (1990) says this approach to engineering ethics "tend to focus upon relatively rare, narrowly bounded crises portrayed against an otherwise happy background of business as usual... (The) contexts that underlie particular cases are never themselves called into question" ( $p$. 53-54). Explanations tend to ignore the analysis presented above, the way engineers become embedded in management systems and modes of decision making and how their freedom is restricted in that they typically work in "hierarchical organisations and have little room to follow their own choices" (Swiestra and Jelsma 2006, p.314). Davis (2012) is somewhat dismissive of this idea in that he argues that engineers can break off their association with their employer at any time just by giving notice. There are many problems with this view of the employment relationship. One of them is that Davis's approach would seem to rely, to a large extent, on the heroism of individual engineers. But Hodson (2001) suggests that professional workers are least likely to engage in conflict with management. Given their considerable investment in becoming professional workers they are unlikely to jeopardize their careers by overt conflict with management. There is evidence from disaster investigations which suggests that employees were aware of problems before disasters occurred but were either too anxious about damaging their career prospects to raise their concerns, or had raised concerns and these had been largely ignored (Agapiou 2005). Another problem is that even if the engineer breaks off their association with their employer this may not lead to change or the ending of or unethical practices.

It seems that engineers are to meet their obligations to the public "regardless of any pressure they may encounter working in a corporate environment" (Lynch and Kline 2000, p.197) or regardless of the cost of whistleblowing which can be significant (Agapiou 2005), and that individual acts of resistance can happen in a vacuum: "A solid grounding in moral philosophy, a personal moral code, and a commitment to professional responsibility are assumed to inoculate us from the weakness of will'. (Lynch and Kline 2000, p.207). The emphasis is on changing engineers rather than changing the context. By not addressing the structural context in which engi-

\footnotetext{
3 A recent systematic review, covering 21 journals in engineering educations and ethics, examining the relationship between risk management and ethics found that analysis of risk and safety is often devoid of complexity and context. It suggests that risk management is mostly used as an anecdote or an example when addressing ethics issues in engineering education. Further, it is perceived as an ethical duty or requirement, achieved through rational and technical methods. Only a small number of publications offer critical analyses of ethics education in engineering (Guntzburger et al. 2016).
} 
Pre Publication Copy.Refer to book for page numbers when quoting

This is chapter 3 of Steen Hyldgaard Christensen, Bernard Delahousse • Christelle Didier,Martin Meganck • Mike Murphy (eds)

The Engineering-Business Nexus:Symbiosis, Tension and Co-Evolution. Springer, 2019. It appears on pages $39-59$

neering takes place there is a danger of moralism as unrealistic expectations are placed on engineers.

Secondly, it seems to ignore much of the research on accident causation which suggests that "attempts to find an identifiable culprit (should) not obscure the more subtle causes of failure which are typically... rooted in the social and organisational properties of the overall sociotechnical system" (Pidgeon 1992, p.18). These causes recur in disparate engineering sectors. Yves Dien and others (2004) have identified recurrent features of "organisational accidents". In doing so they argue that

\footnotetext{
the scientific community involved in the field of accident study agrees on the fact that if any event (accident, incident or crisis) is generated by direct and immediate causes ("human errors" among others), it has been induced and favoured by underlying local causes or conditions (specific technical and ergonomic conditions, local modes of personnel management, environmenta characteristics, etc.) and more global organisational conditions which may be at the origin of the local conditions or have an impact on the direct or immediate causes (p. 148)
}

Accidents have an historical background and an unfavourable organisational context in as much as a number of decisions and unfavourable circumstances progressively generate a pre-accident situation long before the triggering of the accident itself. Accidents can be seen to have an incubation period when multiple predisposing factors accumulate. A trigger event then provokes the onset of the accident. The recurrent factors identified by Dien et al. (2004) include:

1. Weakness of the organisational safety culture;

2. Complex and inappropriate organisation;

3. Limits of operational feedback;

4. Failure of the control organisations; and

5. Production pressures.

It can be noted that many of these causes emanate from the essentially capitalist character of modern organisations entailing as they do a focus on profit and hierarchal modes of decision-making. Those using an approach based on Marxist political economy (Nichols 1997, Pearce and Tombs 1998, Tombs 2007/8, Tombs 2010) seek to locate these causes in broader economic and political relations and the "process of capital accumulation and the relation between different classes" (Nichols 1997, p.82). Pearce and Tombs (1998) draw explicitly on CR to argue that much work on accident causation concentrates on first-order empirical causes, such as immediate production pressures, bad communications and training, and less on second-order underlying processes which generate empirically identified first-order causes. In explaining "safety crimes" Tombs argues for an approach which places their production within "prevailing systems of economic, social and political organisation, dominant value systems and beliefs, and the differential distribution of power." (2007/8, p. 29). He argues that there is a need to consider factors ranging from the individual through to the structural, operating at four analytically distinct levels. Individuals need to be placed in the structures in which they operate and this means taking account of their immediate work group, workplace, company and the wider environment in which the company operates. This leads to a focus on the relationship between profit and safety, management and workers, the role of the state in regulating 
Pre Publication Copy.Refer to book for page numbers when quoting

This is chapter 3 of Steen Hyldgaard Christensen, Bernard Delahousse • Christelle Didier,Martin Meganck • Mike Murphy (eds)

The Engineering-Business Nexus:Symbiosis, Tension and Co-Evolution. Springer, 2019. It appears on pages $39-59$

safety and supporting a "voice" for workers and state business relations. In this context the advent of neo-liberal regimes with commitments to deregulation and the valorisation of risk has had a detrimental effect on workplace safety. What is significant about this approach is that it seeks to integrate mechanisms operating at different levels into explanations of management and worker interactions and their effects on safety. It focuses on the distribution of power and

exposes as socially specific what is taken for granted, revealing how what is, was not always so, and need not necessarily be, with existent states of affairs only comprehensible in the context of macro-level social processes, on both national and international levels (2007/8 p.30).

This approach does not argue that there is always a conflict between safety and profits. There may be a coincidence of interest between accumulation and safety, whereby improvement in safety may go hand in hand with improvement in profit, particularly when a major disaster or a record of consistent accidents and injuries may disrupt the production process or make it hard to recruit employees. Further, some companies engage in long-term calculations of profitability and are more likely to provide safer workplaces (Nichols 1997, Pearce and Tombs 1998). Notwithstanding this, Pearce and Tombs argue that it would be "ludicrous to ignore the dynamic tendency to accumulate within a capitalist society since this provides the raison d'etre of the private corporation". They say there is an ultimate and inevitable truth to the argument that profit maximisation is the most fundamental cause of accidents - "it is accurate in the last instance". But they are keen to avoid the implication that accidents are therefore inevitable. There is a danger that posing a mutual exclusivity between safety and profits leads to political passivity as accumulation takes precedence over all other goals and reforms are rendered unlikely. They argue for the need to develop an appreciation of how the drive for accumulation is articulated with second-order causes and counter-tendencies to accidents and thereby consider how they might be prevented (1998, pp.134-5). Therefore a greater degree of equality in workplace relations is required if "distorted communication" is to be overcome: "it is often workers themselves (including engineers) who first and accurately recognise the dangers associated with particular production processes only to have this recognition ignored" (p. 144).

In this context the roles of regulation and worker participation in organisational decision assume significance. Some approaches to engineering ethics have focused on specific changes in structures of corporate and management accountability including holding senior executives responsible for accidents and deaths and for strict penalties, including imprisonment, when their organisation is found guilty (De George, 1981). Henk Zandvoort (2005) has proposed wide ranging changes to legal systems to enable socially responsible behavior in engineering and the promotion of sustainability, including a regime of strict liability. He also argues for changes to the laws governing responsibility in organisations and proposes that organisations operate on the basis of 'shares of responsibility' for their activities. Underlying this work is the recognition that "If the engineers claims for safety have to survive in a context dominated by competition for money and power, regulation with an ethical content may be the engineers life jacket" (Coeckelbergh 2006). But given the role of the state in encouraging capital growth and mobility we must be circumspect 
Pre Publication Copy.Refer to book for page numbers when quoting

This is chapter 3 of Steen Hyldgaard Christensen, Bernard Delahousse • Christelle Didier,Martin Meganck • Mike Murphy (eds)

The Engineering-Business Nexus:Symbiosis, Tension and Co-Evolution. Springer, 2019. It appears on pages $39-59$

about the stability of regulatory gains and the possibility of them being swept away by policies aimed at altering the balance of class relations such as those emanating from the current neo-liberal consensus. Thus there is an onus on us to consider "alternative means of organising production regimes that will neither encourage nor sustain the routine killings, injuries, disease and widespread emiseration of lives wreaked by corporations" (Tombs 2010, p.899).

\section{Climate Dilemmas}

This issue also arises for engineers in the context efforts to address the challenge of climate change. According to Jowitt (2010) one of the tasks, of truly global proportions, confronting engineers in the twenty-first century is engineering the world to avert an environmental crisis in terms of energy use, greenhouse gas emissions and their contribution to climate change. While engineers are encouraged to promote and practice the principles of sustainable development most of the focus in engineering is on evaluating technical reliability and environmental impact (Lucena 2010).

For Marx there is a fundamental contradiction between nature and capitalism: "Capitalist production...develops technology, and the combining together of various processes into a social whole, only by sapping the original sources of all wealth the soil and the labourer" (Quoted in Burkett 2005), p.80). Marxists would argue that there is a rapidly intensifying contradiction between capitalist relations of production and the survival of human and other species (Magdoof and Foster 2011). This contradiction between the needs of the economic system and the requirement of sustainability may undermine the efforts of engineers in delivering a sustainable future. For engineers a key question is whether "technical change can reduce the impact of economic development sufficiently to ensure other changes will not be necessary" (Beder 1998, p.198). There is evidence to suggest otherwise.

In its Fifth Assessment Report the International Panel on Climate Change (IPCC) showed that total Greenhouse Gas Emissions increased between 1970 to 2010, with larger absolute increases between 2000 and 2010, despite a growing number of climate change mitigation policies. While globally, economic and population growth continued to be the most important drivers of increases in $\mathrm{CO} 2$ emissions the IPCC goes on to say: "The contribution of economic growth has risen sharply." (IPCC 2014, p.5).

In order to test the feasibility of the European Union (EU) meeting its targets for 2020, Finish researchers analyzed carbon dioxide emissions between 1993-2004. Although emissions in the entire Union grew only by an average of $0.31 \%$ per year, emissions and their drivers varied markedly among the 27 member states. Dematerialization and decarbonization did occur, but not enough to offset the slight population growth plus rapidly increasing affluence. In order to fulfill its obligation to 2020 the EU27 will have to counter its increasing population and affluence by a combined dematerialization and decarbonization 1.9-2.6 times faster than during 1993-2004. (Saikku et al. 2008). Ireland faced a particular difficult task as the strongest upward drivers were changes in population $(1.2 \% /$ year) and, most im- 
Pre Publication Copy.Refer to book for page numbers when quoting

This is chapter 3 of Steen Hyldgaard Christensen, Bernard Delahousse • Christelle Didier,Martin Meganck • Mike Murphy (eds)

The Engineering-Business Nexus:Symbiosis, Tension and Co-Evolution. Springer, 2019. It appears on pages $39-59$

portantly, affluence (6.9\%/year) again undermining the decarbonization that had occurred. Therefore, it is unsurprising to learn that Ireland was only able to meet its commitments under the Kyoto Protocol due to the great recession, which began in 2008, and which led to an almost complete collapse of the economy. According to the Environmental Protection Agency (2013): "Whilst the reduction in the distance to target for the Kyoto Protocol period is a positive outcome in terms of compliance, its occurrence is, primarily, a direct result of the current economic recession and economic outlook for the future."

There are two other issues that should be highlighted in relation to emissions. Firstly, emission reductions in developed countries often result from the export of emissions. Data for 2014, provided by the Tyndall Centre for Climate Change Research, shows that while the EU had decreased its emissions by 1.8 per cent it continued to export a third of its emissions to China and other producers through imported goods and services (Tyndall Centre 2014). The accounting of these emissions is problematic in that current methods tend to focus on production related emissions. A focus on the final point of consumption would show very different trends in emissions, particularly in developed countries. Helm et al.'s (2007) analysis of Britain's emissions shows that rather than a $2.1 \%$ per annum decrease since 1990 , a consumption related inventory approach, which include emissions embedded in imports, shows that emission have actually increased by $19 \%$.

This trend to offshore emissions is a direct result of investment and profit seeking activities of major corporations (Malm 2016) ${ }^{4}$. Andreas Malm, using a Marxist framework, presents some stark facts to show how China's full integration into the global economy, following its membership of the World Trade Organization in 2001 and the dismantling of barriers to foreign investment, led to an explosion of emissions. While investment decisions were driven by the availability of compliant and cheap labor, with costs less than $5 \%$ those of the US or the EU, the growth in emissions was due to Chinas high carbon intensity. As much as $48 \%$ of its emissions between 2002 and 2008 were generated in the export sector which is dominated by foreign companies (FIEs) (p.339). He concludes that "Given the role of FIEs in Chinese exports, and that of exports in Chinese emissions, we may thus infer that the quest for maximum surplus-value was indeed a paramount mechanism for igniting the explosion" (p.342).

Secondly, emissions result mainly from the activities of a relatively small but well off group of people. Work by Stephen Pacala (2007), Director of the Princeton Environmental Institute, shows that the top 500 million emitters are responsible for half of the world's greenhouse emissions. Because of the tight correlation between income and emissions, the top 500 million emitters are also the 500 million richest people. Two-thirds live in developed countries, but fully one-third live in developing countries. In contrast, the 3.1 billion poorest and lowest emitting people (the bottom half of the global distribution) are responsible for only $5-10 \%$ of the world's emis-

\footnotetext{
${ }^{4}$ This should caution us against simply blaming consumers in the developed world for the growth in emissions. Indeed it is often workers in the richer countries who are the most vigorous opponents of offshoring jobs to havens of cheap labor (and high emissions). It should also make us sceptical about corporate claims to be going green.
} 
Pre Publication Copy.Refer to book for page numbers when quoting

This is chapter 3 of Steen Hyldgaard Christensen, Bernard Delahousse • Christelle Didier,Martin Meganck • Mike Murphy (eds)

The Engineering-Business Nexus:Symbiosis, Tension and Co-Evolution. Springer, 2019. It appears on pages $39-59$

sions. Given this it is not surprising that "mitigation and adaptation raise issues of equity, justice, and fairness. Many of those most vulnerable to climate change have contributed and contribute little to GHG emissions". (IPCC 2014, p.17).

It seems then that the work of many engineers in generating technological efficiencies are being undermined by economic growth. This is unsurprising given what is known as Jevons Paradox, after William Stanley Jevons who, following his study of the use of British Coal in the 1800s, argued that the increased efficiency of coal would not lead to a diminished demand for it (Foster et. al. 2010). John Bellamy Foster and others (2010) argue, as Marxists, for its use in understanding current trends and that improvements in energy efficiency can lower the effective cost of various products, propelling the overall economy and expanding overall energy use. They argue that much analyses of the Jevons Paradox have remained abstract and based on isolated technological effects. Its impact has to be understood at the macro level and in the context of capitalism as a system which will tend to use any efficiency gains to expand the overall scale of production. Pessimistically they conclude, based on historical evidence (which Huesemann (2003, p.30) summarises as telling us that "technological innovation has never been used to stabalize the size of the economy; in fact quite the opposite, namely the enhancement of industrial productivity, consumption and economic growth"), that "conservation in the aggregate is impossible for capitalism, however much the output/input ratio may be increased in the engineering of a given product" (p.10). While I am not addressing the issue of the transition to an energy system based on renewables here ${ }^{5}$, it is can be noted that the global record for the period from 1960 to 2009 is that 1 kilowatt-hour of renewable electricity replaces an average of 0.1 kilowatt-hour of fossil electricity (York 2012). Rather than replace fossil fuels, renewable have added to an evergrowing energy pie leaving them to compete in an energy market driven by supply and demand.: "If solar and wind were to become radically cheaper than fossil fuels, demand for the later might fall - only to induce a corresponding fall in their prices, reviving demand and establishing an equilibrium of profligacy" (Mahm 2016, p.382)

It seems useful then to locate the pattern of emission increases in the operation of the global economic system, its thirst for growth and profit and the pattern of class relations. Viewing the problem in national terms seems unhelpful given that it is rich people across the globe who are benefiting most from increased growth and contributing to a climate crisis which will impact most on those who have least. Klein (2014) argues that neo-liberal policies that privilege elites and free corporations from constraints are those that have contributed most to rising emissions. Summarising data from a range of sources she says:

The numbers are striking: in the 1990s, as the market integration project ramped up, global emissions were going up an average of 1 per cent per year; by the 2000s, with emerging markets like

\footnotetext{
${ }^{5}$ See Malm (2016, Chapter 15) for an excellent analysis. He highlights the manner in which the transition is fettered by capitalist relations of production and the withdrawal from investment in wind and solar by major corporations due to low levels of profitability: "capital did not engage in the transition as many had expects it would, largely because energy from the flow (wind and solar) lost so much of its exchangevalue at the very same time that its social use-value -slowing down climate change- rose towards priceless heights" (p.371 emphasis in original).
} 
Pre Publication Copy.Refer to book for page numbers when quoting

This is chapter 3 of Steen Hyldgaard Christensen, Bernard Delahousse • Christelle Didier,Martin Meganck • Mike Murphy (eds)

The Engineering-Business Nexus:Symbiosis, Tension and Co-Evolution. Springer, 2019. It appears on pages 39-59

China now fully integrated into the world economy, emissions growth had sped up disastrously, with the annual rate of increase reaching 3.4 percent for much of the decade. The rapid growth continues to this day, interrupted only briefly in 2009 by the world financial crises (2014, p. 20).

Ominously in 2010 they increased by nearly 6\%: the largest absolute increase since the Industrial Revolution (p.18). Such trends have led to some leading climate scientists, such as Kevin Anderson at the Tyndall Centre, described by Kline as "spikeyhaired former mechanical engineer" (2014, p.87), to argue that the kinds of cuts needed cannot be achieved without immediate degrowth strategies (Anderson and Bows-Larkin 2010, Anderson 2013). He claims that wealthier nations need to reduce their emissions by between 8 and $10 \%$ per annum but that he can find no examples, despite lengthy literature searches, of economists suggesting that prolonged emission reductions above 3 to $4 \%$ are economically sustainable.

The demand for degrowth is not unproblematic. Some working in a Marxist framework have rightly posed the question as to whether degrowth is achievable without fundamentally changing the nature of our economic system. The levels of degrowth required could be such as to impoverish large sections of the population through escalating levels of unemployment. Minqi Li (2008) has examined various scenarios for emissions reductions by examining the interaction of reductions in emission and energy intensity and economic growth consistent with a target of keeping global warming below 2 degrees. He concludes, even where the declines in emissions and energy intensity are optimistic in comparison with the historical record, that the world economy would have to fall by two-thirds to three quarters to 2050 to keep warming below 2 degrees. Fred Magdoof and John Bellamy Foster (2011) have examined the post war relationship between growth and unemployment in the USA and conclude that only in the 13 years when growth was in excess of $5 \%$ did unemployment not increase at all.

What is suggested here is that we need to move beyond the social, economic and power relations of capitalism. Degrowth can only take on genuine meaning as part of a critique of capital accumulation as it violates the basic motive force of capitalism. We "must aim not merely for degrowth in the abstract but... a transition away from a system geared to the accumulation of capital without end" to one that meets "the common needs of humanity and the earth" (Foster 2011).

What this means in practice, for engineers and others, may be gleamed from a journal closer to the engineering domain. In a Special Issue on degrowth the Journal of Cleaner Production carries contributions from the Second International Conference on Degrowth and seems to suggest that some of those arguing for degrowth are cognisant of the need to alter current economic relations and practices. In its editorial (Sekilova et. al 2013) we discover that degrowth entails a downscaling of "the role of markets and commercial exchanges as a central organising principle of human lives"; "rethinking needs and shifting objectives away from the regime of accumulation in monetary terms"; "setting binding macro level constraints" and not just relying on "simple individual action"; and "institutional changes starting with the abandonment of the corporate structure as a form of productive organisation". These actions might set us an a path towards Marx's "Vision of Sustainable Human Development" in a society "organised for cooperative working on a planned ba- 
Pre Publication Copy.Refer to book for page numbers when quoting

This is chapter 3 of Steen Hyldgaard Christensen, Bernard Delahousse • Christelle Didier,Martin Meganck • Mike Murphy (eds)

The Engineering-Business Nexus:Symbiosis, Tension and Co-Evolution. Springer, 2019. It appears on pages $39-59$

sis...to ensure all members of society the means of existence and the full development of their capacities" (Quoted in Burkett 2005, p.5).

\section{Conclusion}

The analysis presented here suggests there are significant constraints on engineering practice, emanating from the corporate environment, which affect engineers capacities to hold paramount the health, safety and welfare of the public. The central contradiction of capitalism, between the forces and relations of production, ensures that potential in engineering to further human welfare and protect the environment will always be fettered by capitalist relations of production. The structural location of engineers within corporations creates pressure for conformity with managerial agendas. In contrast to some who have argued for the captivity of engineering (eg Noble 1977) the approach adopted here is not deterministic in that there is scope, within the constraints of the system, and given its many contradictions, which invariably leads to resistance, to further agendas which may not always be in the interest of corporations. But engineers cannot, and will not, be able to further such agendas by themselves. A key insight of Science and Technology Studies is that technology and society are co-determined: engineers do not just produce technology, but sociotechnical systems which shape human activity (Johnson and Wetmore 2007). Thus engineers' must engage with other actors who are responsible for the development of socio-technical systems. It is also possible that through alliances with other workers engineers can further demands for democratic reform of work, share technical and production knowledge and "struggle against the waste of people, resources and the environment that capitalism produces" (Meiksins and Smith 1996, p.382).

In the language of CR there are countervailing mechanisms at work: the social structure conditions but does not determine leaving scope for change. Archer (1995) has argued for the importance of historical time in understanding agency/structure relations. While structures predate agency and are dependent on activity, those actions that produce a given structure may be those of a past generation. Once these differential temporalities of structure and agency are taken into account it becomes necessary to differentiate the two and examine their interplay. In order to do so, Archer (1995) has proposed her morphogenetic model of explanation which works on the basis of a three part cycle of analysis:

a) Structural conditioning: pre-existence structures as generative mechanisms that condition but do not determine;

b) Social interaction: their interplay with other objects including agents possessing causal powers leading to

c) Structural elaboration or modification: non-predictable but explicable outcomes arising from the interactions between the above.

The model allows us to focus on the interplay between structure and agency and the possibility of change arising from social interactions over time: "social interaction elaborates upon the composition of the social structure(s) by modifying...structural 
Pre Publication Copy.Refer to book for page numbers when quoting

This is chapter 3 of Steen Hyldgaard Christensen, Bernard Delahousse • Christelle Didi-

er,Martin Meganck • Mike Murphy (eds)

The Engineering-Business Nexus:Symbiosis, Tension and Co-Evolution. Springer, 2019. It

appears on pages $39-59$

relationships and introducing new ones where morphogenesis is concerned". Alternatively, it may lead to morphostasis when structural relations are simply reproduced. (p.169). In William Lynch's recent contribution to engineering ethics he states that: "it is possible that a larger systematic change to established practices over a longer period of time may have a greater chance of being effective than pinning one's hope on heroic intervention at the last moment" (Lynch 2015). In effect he is arguing for a shift from a focus on individual engineers to the structural conditioning of their practice over time.

The challenge to established practices must involve a challenge to the dominance of corporations as a key factor conditioning the practice of engineering. Changing it involves interventions, by engineers and others, in the public policy domain to regulate and ultimately change current practices. Thus we need to examine the kinds of project engineers pursue and how their interventions contribute to the structural conditioning of engineering practice into the future. Therefore $\mathrm{CR}$ provides a basis for placing second order responsibilities on engineers to strive for the creation of supportive social environments which enable their social responsibility (Conlon 2015). This requires us to abandon value neutrality and identify the features of the social structure which need to change in order to facilitate engineering practices which promote safety, sustainability and social justice. It also involves a commitment to engineering activism, engagement with anti-corporate actors such as social movements and trade unions and inevitably an engineering politics (Karwat et al. 2015, Mitcham and Nan 2015). In this context there is a responsibility on those educating engineers to provide students with a sense that change is necessary and possible and that there are alternatives to market based systems which constrain the activities of engineers. Without a sense that there are alternatives agency fails to have any real meaning as outcomes are predetermined.

\section{References}

Agapiou, A. (2005). Whistle-Blowing Protection Provisions for Construction Industry Employees. Construction Information Quarterly, 7 (4), 135-141.

Anderson, K., Boyett, J., et al (2010). Understanding Engineering Work and Identity: A Cross-Case Analysis of Engineers Within Six Firms, Engineering Studies, 2 (3), 153-174.

Anderson, K. and Bows-Larkin, A. (2010) Beyond 'Dangerous' Climate Change: Emission Scenarios for a New World. Philosphical Transactions of the Royal Society A, 369, 20-44.

Anderson, K. (2013). Avoiding Dangerous Climate Change Demands De-Growth Strategies from Wealthier Nations. Available at http://kevinanderson.info/blog. Accessed 01-06-16.

Archer, M. (1995). Realist Social Theory. Cambridge University Press.

Beder, S. (1998). The New Engineer, Macmillan: Sydney

Benton, T. and Craib, I. (2011). Philosophy of Social Science. $2^{\text {nd }}$ ed. Basingstoke: Palgrave

Bowen, W.R. (2014). Engineering Ethics: Challenges and Opportunities. London: Springer.

Braverman, H. (1974). Labour and Monopoly Capitalism. New York: Monthly Review Press.

Brown, R.K. (1998). The Employment Relationship in Sociological Theory. In D. Gaille (Ed.). Employment in Britain. Oxford: Basil Blackwell.

Burkett, P. (2005). Marx's Vision of Sustainable Human Development. Monthly Review, 57 (5). Available at http://monthlyreview.org/2005/10/01 Accessed 01-02-15.

Burowoy, M. (1985). The Politics of Production. London: Verso.

Collier, A. (1994) Critical Realism. London: Verso.

Carter, B. and New, C. (2004). Making Realism Work. Abingdon: Routledge.

Carchedi, G. (1977). On the Economic Identification of Social Classes, London: Routledge.

Coeckelbergh, M.(2006). Regulation or Responsibility? Autonomy, Moral Imagination and 
Pre Publication Copy.Refer to book for page numbers when quoting

This is chapter 3 of Steen Hyldgaard Christensen, Bernard Delahousse • Christelle Didi-

er,Martin Meganck • Mike Murphy (eds)

The Engineering-Business Nexus:Symbiosis, Tension and Co-Evolution. Springer, 2019. It

appears on pages $39-59$

Engineering. Science,Technology and Human Values, 31(3), 237-260.

Conlon, E. (2008). The New Engineer: Between Employability and Social Responsibility. European Journal of Engineering Education, 33(2), 151-159.

Conlon, E. (2013). Broadening Engineering Education: Bringing the Community In. Science and Engineering Ethics, 19(4), 1589-1594.

Conlon, E. (2015). A Critical Realist Approach to Engineering Ethics. IEEE International Symposium on Technology and Society (ISTAS). Dublin, November 2015.

Conlon, E. and Zandvoort, H. (2010). Broadening Ethics Teaching in Engineering: Beyond The Individualistic Approach. Science and Engineering Ethics. 17 (2), 217-232.

Cooley, M. (1978). Design, Technology and Production For Social Needs. In K. Coates, (Ed.). The Right to Useful Work, Nottingham: Spokesman.

Craib, I. (1992). Modern Social Theory. $2^{\text {nd }}$ ed. New York: St. Martin's Press.

Danermark, B., Ekström, M., Liselotte Jakobsen, L. \& Karlsson, J.C .(2002). Explaining Society. Critical Realism in the Social Sciences. London and New York: Routledge.

Davis, M. (2012). "Ain’t no one here but us social forces": Constructing the Professional Responsibility of Engineers. Science and Engineering Ethics, 18 (1), 13-34.

De George, R.T. (1981). Ethical Responsibilities of Engineers in Large Organizations: The Pinto Case. Business \& Professional Ethics Journal, 1(1), 1-14.

Dien, Y., M. Llory, and R. Montmayeul. (2004). Organisational Accidents Investigation Methodology and Lessons Learned. Journal of Hazardous Materials, 111(1-3), 147-153.

Edwards, P. (1986). Conflict at Work. Oxford: Blackwell.

Edwards, P. and Wajcman.J. (2005). The Politics Of Working Life. Oxford University Press.

Environmental Protection Agency (2013). Ireland's Greenhouse Gas Emission Projections 2012-2030. Dublin: EPA.

Foster, J.B., Clark, B. and York, R. (2010) Capitalism and the Curse of Energy Efficiency: The Return of Jevons Paradox. Monthly Review, 62 (6). Available at http://monthlyreview.org/2010/11/01. Accessed 05-04-2016.

Foster, J.B. (2011) Capitalism and Degrowth: An Impossibility Theorem. Monthly Review, 62 (8). Available at http://monthlyreview.org/2011/01/01. Accessed 05-04-2016.

Friedman, A.L. (1977). Industry and Labour. Basingtonstoke: Lacmillan.

Goldman, S. L. (1991). The Social Captivity of Engineering. In P. T. Durbin (Ed.). Critical Perspectives on Non-Academic Science and Engineering. Bethlehem: Lehigh University Press.

Guntzburger, Y., , Thierry C. Pauchant, T.C. and Tanguy, P.A. (2016) Ethical Risk Management Education in Engineering: A Systematic Review, Science and Engineering Ethics, First Online, Available at http://link.springer.com/article/10.1007/s11948-016-9777-y. Accessed 01-05-2016.

Harvey, D. (2007). A Brief History of Neo-liberalism. Oxford University Press.

Helm, D., Smale, R. and Phillips, J. (2007). Too Good To Be True? The UK's Climate Change Record. Available at http://www.dieterhelm.co.uk/publications/Carbon record 2007.pdf. Accessed 01-062015 .

Hodson, R. (2001). Dignity at Work. Cambridge University Press.

Holt, J.E. (2001). The Status of Engineering in the Age of Technology, International Journal of Engineering Education, 17(6), 496-501.

Huesemann, M.H. (2003). The Limits of Technological Solutions to Sustainable Development. Clean Technologies and Environmental Policy, 5, 21-34.

Hyman, R. (1987). Strategy or Structure: Capital, Labour and Control. Work, Employment and Society, $1(1), 25-55$.

Hyman, R. (2006). Marxist Thought and The Analysis of Work, In M. Korczynski, R. Hodson, R. and P. Edwards (Eds) Social Theory at Work. Oxford University Press.

IPCC (2014). Climate Change 2014: Synthesis Report. Fifth Assessment Report of the Intergovernmental Panel on Climate Change. IPCC, Geneva, Switzerland..

Jamison, A. (2013). The Making of Green Engineers. San Rafael: Morgan and Claypool.

Jowitt, P. (2010) Engineering, Innovation, Social and Economic Development. In Engineering: Issues, Challenges and Opportunities for Development, UNESCO.

Karwat, D.M.A., Eagle, W.E., Wooldridge, M.S. and Princent, T.E. (2015). Activist Engineering: Changing Engineering Practice by Deploying Practice. Science and Engineering Ethics, 21 (1), 227-239.

Klein, N. (2014). This Changes Everything: Capitalism vs The Climate. London: Allen Lane.

Korczynski, M., Hodson, R. and Edwards, P. (2006). Introduction to Social Theory at Work. Oxford University Press. 
Pre Publication Copy.Refer to book for page numbers when quoting

This is chapter 3 of Steen Hyldgaard Christensen, Bernard Delahousse • Christelle Didi-

er,Martin Meganck • Mike Murphy (eds)

The Engineering-Business Nexus:Symbiosis, Tension and Co-Evolution. Springer, 2019. It

appears on pages 39-59

Kotta, L. (2011) Engineering Education, Practice and Engineering Research: Critical Realist Insights. Proceedings of the AAEE Conference, 5, 2011, 19-29.

Lee, G.L. and Smith, C. (1992) Engineers and Management. London and New York: Routledge.

Li, M. (2008). Climate Change, Limits to Growth, and the Imperative for Socialism. Monthly Review, 60 (3). Available at http://monthlyreview.org/2008/07/01. Accessed 05-04-2016.

Lucena, J., Schneider, J. and Leydens, J.A. (2010). Engineering and Sustainable Community Development, Morgan and Claypool.

Lynch, W. (2015). Second Guessing Scientist and Engineers: Post Hoc Criticism and the Reform of Practice in Green Engineering. Science and Engineering Ethics, 21 (5), 1217-40.

Lynch, W.T. and Kline, R. (2000). Engineering Practice and Engineering Ethics. Science, Technology and Human Values, 25 (2), 195-225.

MacKenzie, D. (1996). Knowing Machines. Cambridge: MIT Press.

Magdoff, F. and Foster, J. B. (2011). What Every Environmentalist Needs to Know About Capitalism. New York: Monthly Review Press.

Marx, K. (1954). The Eighteenth Brumaire of Louis Bonaparte. Moscow: Foreign Languages Pub. House.

Malm, A. (2016). Fossil Capital. London and New York: Verso.

Meiksins, P. and Smith, C. (1996). Engineering Labour. London and New York: Verso.

Mitcham, C. and Nan, W. (2015). From Engineering Ethics to Engineering Politics. In Christensen, S.H., Didier, C., Jamison, A., Meganck, M.,Mitcham, C., Newberry, B. (Eds.) Engineering Identities, Epistemologies and Values, Engineering Education and Practice in Context, Volume 2, Dordrecht:Springer.

Morgan, G. (1997). Images of Organisations, Thousand Oaks: Sage.

Nichols, T. (1997). The Sociology of Industrial Injury. London: Mansell.

Noble, D. (1977). America By Design. Oxford University Press.

Pacala, S. (2007). Equitable Solutions to Greenhouse Warming: On the Distribution of Wealth, Emissions and Responsibility Within Emissions and Responsibility Within and Between Nations. Lecture to International Institute for Applied Sytem Analysis, November 2007. Available at http://www.precaution.org/lib/pacala_wealth_and_gw.090601.pdf. . Accessed: 01-06-2015

Pearce, F. and Tombs, S. (1998). Toxic Capitalism. Dartmouth: Ashgate.

Pidgeon, N. (1992) The Psychology of Risk. In D. Blockley (Ed.) Engineering Safety, Maidenhead: Mc Graw Hill.

Porpora, D. V. (1998). Four Conceptions of Social Structure. In M. Archer, R. Bhasker et al. (Eds.) Critical Realism: Essential Readings. London and New York: Routledge.

Reed, M. (2005).The Agency/Structure Dilemma In Organization Theory: Open Doors And Brick Walls. In C. Knudsen and H. Tsoukas (Eds.) (2005), The Oxford Handbook Of Organization Theory, Oxford University Press.

Saikku, L., Rautiainen, A. and Kauppi, P.E. (2008) The Sustainability Challenge of Meeting Carbon Dioxide Targets in Europe By 2020 Energy Policy, 36 (2), 730-742.

Scott, D. (2000). Realism and Educational Research: New Perspectives and Possibilities. London: Routledge.

Seiklova, F., Kallis, G., et al. (2013) Degrowth: From Theory to Practice. Journal of Cleaner Production, $38,1-6$.

Smith C. (1987). Technical Workers, Class, Labour and Trade Unionism. London: Macmillan.

Smith, C. and Meiksins, P. (1995) System, Society and Dominance Effects in Cross-National Organisational Analysis. Work Employment and Society, 9 (2), 241-267.

Swierstra, T. and Jelsma, J. (2006). Responsibility Without Moralism in Technoscientific Design Practice. Science, Technology and Human Values, 31(3), 309-332.

Thompson, T. and Mc Hugh, D. (2002). Work Organisations. $3^{\text {rd }}$ ed. Basingstoke: Palgrave.

Tombs, S. (2010). Corporate Violence. In F. Brookman, H. Pierpoint, T. Bennett and M. Maguire (Eds) Handbook on Crime, Cullompton: Willan, 884-903.

Tombs, S. (2007/8). A Political Economy of Corporate Killing. Criminal Justice Matters, 70 (1), 29-30

Tyndall Centre (2014) CO2 Emissions Set To Reach New 40 Billion Tonne Record High In 2014. Available at http://www.tyndall.ac.uk/communication/news-archive/2014. Accessed: 01-06-2015

Whalley, P. (1986). The Social Production of Technical Work. Basingstoke: Macmillan.

Winner, L. (1990). Engineering Ethics and Political Imagination. In P. Durbin (Ed.) Broad And Narrow Interpretations Of Philosophy Of Technology: Philosophy and Technology 7. Boston: Kluwer.

Woodhouse, E.J. (2001). Curbing Overconsumption: Challenge For Ethically Responsible Engineering, IEEE Technology and Society Magazine, Fall 2001, 23-30. 
Pre Publication Copy.Refer to book for page numbers when quoting

This is chapter 3 of Steen Hyldgaard Christensen, Bernard Delahousse • Christelle Didi-

er,Martin Meganck $\bullet$ Mike Murphy (eds)

The Engineering-Business Nexus:Symbiosis, Tension and Co-Evolution. Springer, 2019. It

appears on pages $39-59$

Wright, E.O. (1979). Class, Crises and the State. London: Verso.

York, R. (2012). Do Alternative Energy Sources Displace Fossil Fuels? Nature Climate Change 2, 441-3.

Zandvoort, H. (2005). Good Engineers Need Good Laws. European Journal of Engineering Education, $30,(1), 21-36$.

Zussman, R. (1985). Mechanics of the Middle Class. Berkeley: University of California Press. 